\title{
Article \\ Quantitative Analysis of Methodological and Environmental Influences on Survival of Planted Mangroves in Restoration and Afforestation
}

\author{
Daniel Gorman ${ }^{1, *(D)}$, Mathew A. Vanderklift ${ }^{1}$ and Anna Lafratta ${ }^{1,2}$ \\ 1 Commonwealth Scientific and Industrial Research Organisation, Oceans and Atmosphere, \\ Indian Ocean Marine Research Centre, Crawley, WA 6009, Australia; mat.vanderklift@csiro.au (M.A.V.); \\ a.lafratta@ecu.edu.au (A.L.) \\ 2 School of Sciences and Centre for Marine Ecosystems Research, Edith Cowan University, \\ Joondalup, WA 6027, Australia \\ * Correspondence: d.gorman@csiro.au; Tel.: +61-402-419-911
}

check for updates

Citation: Gorman, D.; Vanderklift, M.A.; Lafratta, A. Quantitative Analysis of Methodological and Environmental Influences on Survival of Planted Mangroves in Restoration and Afforestation. Forests 2022, 13, 404. https://doi.org/ 10.3390/f13030404

Academic Editors: Victor

H. Rivera-Monroy, Xosé Lois Otero-Pérez, Jorge Lopez-Portillo and Tiago Osorio Ferreira

Received: 18 January 2022

Accepted: 25 February 2022

Published: 2 March 2022

Publisher's Note: MDPI stays neutral with regard to jurisdictional claims in published maps and institutional affiliations.

Copyright: (c) 2022 by the authors. Licensee MDPI, Basel, Switzerland. This article is an open access article distributed under the terms and conditions of the Creative Commons Attribution (CC BY) license (https:// creativecommons.org/licenses/by/ $4.0 /)$.

\begin{abstract}
Mangrove planting has been employed for decades to achieve aims associated with restoration and afforestation. Often, survival of planted mangroves is low. Improving survival might be aided by augmenting the understanding of which planting methods and environmental variables most influence plant survival across a range of contexts. The aim of this study was to provide a global synthesis of the influence of planting methods and background environment on mangrove survival. This was achieved through a global meta-analysis, which compiled published survival rates for the period 1979-2021 and analyzed the influence of decisions about minimum spacing and which life stage to plant, and environmental contexts such as climate, tidal range and coastal setting on the reported survival of planted individuals, classified by species and root morphology. Generalized Additive Mixed Modeling (GAMM) revealed that planting larger mangrove saplings was associated with increased survival for pencil-rooted species such as Avicennia spp. and Sonneratia spp. (17\% increase cf. seedlings), while greater plant spacing was associated with higher survival of stilt-rooted species in the family Rhizophoraceae (39\% increase when doubling plant spacing from 1.5 to $3.0 \mathrm{~m}$ ). Tidal range showed a nonlinear positive correlation with survival for pencil-rooted species, and the coastal environmental setting was associated with significant variation in survival for both pencil- and stilt-rooted species. The results suggest that improving decisions about which species to plant in different contexts, and intensive care after planting, is likely to improve the survival of planted mangroves.
\end{abstract}

Keywords: plant spacing; life stage; coastal environmental setting; plant husbandry; mangroves; restoration

\section{Introduction}

Mangrove forests are highly productive coastal ecosystems distributed worldwide in tropical and subtropical regions [1]. They provide numerous ecosystem services such as coastal protection, enhanced biodiversity, fisheries support, nutrient cycling and climate change mitigation and adaptation by storing carbon [2,3], therefore supporting human well-being and livelihoods [4,5]. However, mangrove forests are one of the most threatened ecosystems on Earth due to climate change and human activities [6]. In particular, forests have been extensively modified or cleared for aquaculture, food production and coastal development, which in many parts of the world continues up until the present [7-9]. Some estimates suggest that up to 35\% of the world's mangrove forests have been damaged or destroyed during the last 20 years $[10,11]$. However, multiple efforts to halt and reserve this trend [12] have slowed the overall rates of loss (e.g., dropping to less than $2 \%$ per year in Asia [13]).

Mangrove restoration has mainly focused on planting, although restoration of tides to places they have been excluded from can also be very effective [14]. Mangroves have 
also been planted for other purposes, sometimes in places where they have not occurred naturally (i.e., afforestation). They can be planted to provide a source of wood or other products, in some cases as part of silviculture, in the same way as terrestrial forests [15]. Mangrove planting is also used to prevent erosion and to stabilize newly accreted coastlines [16]. Restoration programs have increasingly adopted less-intensive methods, such as restoring natural tidal regimes [17], but planting is often still needed.

Mangrove rehabilitation and restoration is considered one of the most effective management options globally for dealing with lost or damaged mangrove forests [12]. Although planting mangroves for restoration and afforestation has been conducted in some regions for more than 50 years (e.g., Bangladesh [16] and Vietnam [18]), it is not always a success. Many biotic and abiotic influences, including, among many others, predation, seed recruitment, soil characteristics, colonization rates, salinity and temperate, can reduce the survival of the mangroves, in both early (e.g., nursery) and late stages of the planting process [19]. Additionally, outcomes can often be unsuccessful because the methods employed are inappropriate (e.g., species selection, plant spacing [20]) and because the species used are not suited to the environment where they are planted (e.g., coastal environmental setting, tidal inundation, soil conditions and physical stress [21-23]). Sometimes, otherwise well-planned and executed mangrove planting efforts fail because of a lack of participation by local communities, cultural barriers and adequate after-care (e.g., watering and removal of objects that are entangled with planted individuals) needed for long-term success [24]. Improving the success of mangrove planting efforts would benefit from a quantitative understanding of the methodological, environmental and social influences on mangrove survival in different contexts [25]. These methods can augment natural regeneration [26] as approaches to restore degraded or lost mangrove forests.

The aim of this study was to provide a global synthesis of influences on mangrove survival after planting, arising from (1) methods used (life stage selected, minimum plant spacing) and (2) environmental context (climate, coastal setting and tidal range). While there are multiple guidelines offering advice on best practices in mangrove restoration (some of which suggest that natural recolonization should be preferred instead of planting), the goal of the present study was to complement these through a quantitative review of influences on survival after the planting stage. This information is intended to help inform planting efforts, including through increasing efficiency and reducing costs [27].

\section{Materials and Methods}

\subsection{Data Collection and Standardization}

A comprehensive literature review was conducted which included journal articles, reports and theses (in multiple languages). This involved searching the databases of Google Scholar, Scopus and the Institute of Scientific Information (ISI) Web of Science for the following search terms: 'mangrove' AND 'restoration' OR 'afforestation' AND 'spacing' AND 'survival'. A parallel search was conducted on Google search engine, using the same words, to identify relevant documents not yet captured in the core scientific literature (e.g., reports from Government, not-for-profit and community initiatives). Reference lists in relevant documents were also checked. Data were extracted from publications that met the requirements of the search ( $9 \%$ theses, $12 \%$ reports and $79 \%$ peer-reviewed journal articles: Supplementary Figure S1).

While the benefits of mixed species planting programs are increasingly recognized [28], the review yielded only two relevant published studies, which did not permit formal inclusion in the analyses. Only studies on monospecific plantations older than six months were included because this was the minimum duration considered necessary to ensure that there were no artefacts of soil disturbance that may have resulted in plant mortality. The following information was extracted directly from the documents: location (latitude and longitude), species, overall goal of planting (restoration or afforestation), life stage planted (i.e., 'seeds', 'propagules', 'seedlings', 'saplings' and 'trees', following the definitions of Vanderklift et al. [25]), minimum distance among plants (m), duration since planting 
(days) and survival rate (\%, mean $\pm \mathrm{SE}$ and $n$, when an average was provided). Species were assigned into functional groups based on root morphology: 'stilt', 'pencil', 'knee', 'knotted' and 'buttress" [29]. If the species identity was not provided, the study was not considered for the dataset. When survival rates were not provided in tables or text, means and estimates of variation (i.e., standard deviation) were extracted from graphs using the program GraphClick version 3.0.2 (Arizona Software Inc., Phoenix, AZ, USA). If a study reported a mean survival rate without providing an error for the mean, data were not included. For studies that reported data on survival rates collected multiple times over time for the same treatment, plot or site, only the last record was included in the dataset.

For each study, information was extracted in relation to the length of time plants were maintained in a nursery prior to planting, any reports of after-care, such as supplementary watering or the removal of debris, and the main reason for mortality, if available. After-care was defined as ongoing actions, such as monitoring, guarding the plantation to avoid improper use, removing plastic debris, restricting trampling and watering, all of which have been shown to enhance survival rates [30,31]. The reasons for mortality were grouped into five categories, described as: 'abiotic' (e.g., salinity, wave energy, light exposure), 'site suitability' (e.g., high or low inundation, planting area), 'competition' (e.g., nutrient limitation), 'predators' (e.g., monkeys, crabs, goats) and 'methodology' (e.g., use of artificial structures, plantation density), and the prevalence of these factors was calculated from all reported studies.

We compiled data on the environmental context of each study from the relevant publication if reported, or from other sources. For example, tidal range was derived using the global dataset on tidal amplitude [32]. For locations where coordinates (latitude and longitude) did not overlap exactly with the data layer provided, the closest coordinates with data available were used. The Köppen-Geiger climate classification system [33] was used to assign each study to one of the following climate groups: tropical (including tropical rainforest, wet and dry or savanna climate), arid (including desert coastlines and semi-arid climate), temperate or subtropical (humid subtropical and monsoon-influenced humid climate). Finally, information on the coastal geomorphological setting for mangrove forests was based on the mangrove typology classifications developed by The Nature Conservancy (http:/ / maps.oceanwealth.org/mangrove-restoration/\#, accessed on 18 December 2020). Each study was assigned to one of the following coastal environmental settings (CES): 'fringe', 'estuary', 'lagoon' or 'delta', using the definitions of Rovai et al. [34] (Supplementary Figure S1).

\subsection{Model Fit, Evaluation and Prediction}

A Generalized Additive Mixed Model (GAMM) approach was used to investigate the survival rates (\%) of planted mangroves. This approach was used because it allows a response variable (in our study 'survival') to be modeled using a combination of fixedorthogonal factors (e.g., life stage), as well as continuous factors (e.g., minimum spacing and tidal range). It also permits non-linear environmental relationships to be modeled which can more accurately identify phenomenon such as ecological thresholds that are common within shallow coastal marine areas. All models were fitted using the ' $\mathrm{mgcv}^{\prime}$ library [35] in the R statistical environment [36]. A logit link function was used together with a cubic smoothing spline to determine the optimum level of smoothing for each continuous environmental predictor [37]. Analyses were performed separately for each root morphology group: 'pencil roots', 'stilt roots' and 'knee roots' (Supplementary Table S2). Although there are other mangrove root morphologies, such as 'buttress roots' and 'knotted roots', there were not sufficient records to permit analysis and thus these were excluded from analyses. Similarly, while there were studies that reported the use of 'seeds' and 'adult trees', these were too few to permit formal analysis and were also excluded.

For each group, a model was applied in the form of: survival rate (\%) life stage + CES + climate zone $+\mathrm{s}$ (minimum spacing) $+\mathrm{s}$ (latitude) $+\mathrm{s}$ (tidal range). Model selection employed a stepwise backwards selection that removed non-significant terms using a significance test 
criterion $(p>0.05)$ until all remaining terms in the model were significant, similar to the approach used by Austin and Van Niel [38]. Selected models were assessed conservatively through comparisons of the score-minimized Un-Biased Risk Estimator (UBRE) [39].

\section{Results}

\subsection{General Trends in Mangrove Restoration}

The compiled dataset included 225 observations from 45 publications (Supplementary Table S2), spanning 24 countries (Figure 1) and 42 years (1979 to 2021). Studies were mostly centered around the tropics (82\%), with fewer from temperate/subtropical regions (17\%) and very few $(>1 \%)$ from arid regions (Figure 1$)$. Most studies were performed for the purpose of restoration (80\%), with fewer studies conducted for afforestation (20\%), with the majority of these involving the use of Sonneratia spp. in places such as the Bay of Bengal. While the ultimate motivations for restoration and afforestation projects can be quite different, distinguishing between these was outside the scope of the present study and all available data were included for modeling purposes. The five most frequently planted genera (i.e., Avicennia L., Bruguiera Lam., Ceriops Arn., Rhizophora L. and Sonneratia L.f.) typically involved planting of seedlings or saplings, with viviparous propagules also often used when planting Rhizophora or Ceriops (Figure 2).

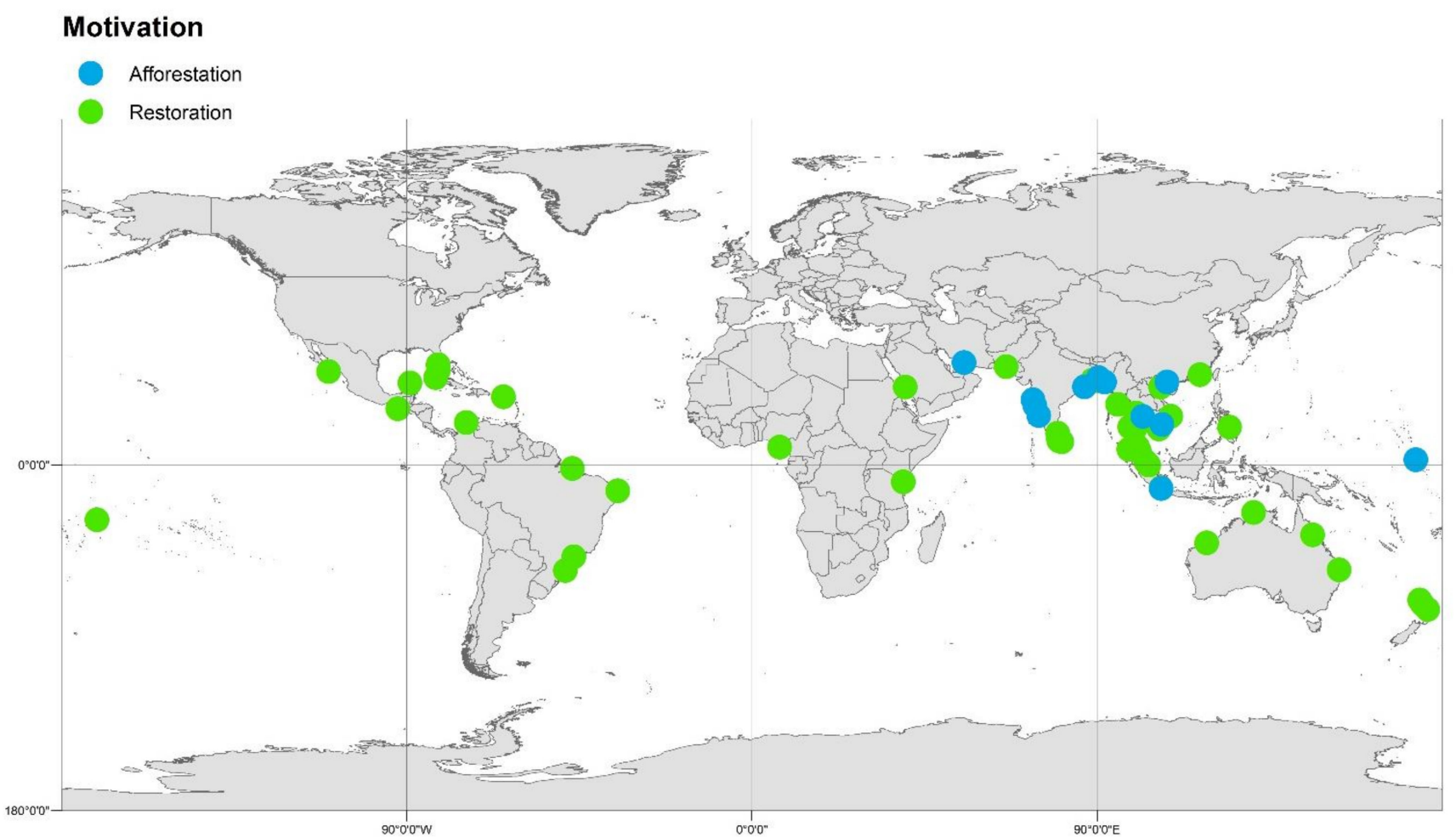

Figure 1. Map of mangrove planting projects included in this current study, with colors indicating the primary motivation for planting.

\subsection{Methodological Context}

Results of GAMM analyses showed that planting methods influenced the survival of pencil- and stilt-rooted mangroves, but not knee-rooted species (Table 1). The survival of planted individuals of pencil-rooted species (Avicennia and Sonneratia) was influenced by the life stage used, with higher survival observed for larger saplings $(61.6 \% \pm 7.4 \%)$ than seedlings $(44.2 \% \pm 3.2 \%$, Figure $3 \mathrm{~A}$ and Table 1$)$. No studies of pencil-rooted species used propagules (e.g., seed capsules or fruits). For stilt- and knee-rooted species, life stage was not a statistically significant influence (Figure 3B,C and Table 1). Neither pencil- nor knee-rooted species showed a statistically significant effect of minimum plant spacing 
(Figure 3D,F), but stilt-rooted species demonstrated a complex nonlinear trend of high survival at small plant spacings $(>0.5 \mathrm{~m})$, followed by a modeled decline $(0.5-1.5 \mathrm{~m})$ and a subsequent increase with larger spacings (Figure 3E).

\subsection{Environmental Context}

Latitude did not appear to influence survival in any group (Figure 4G-I), although studies involving pencil-rooted species covered a wider latitudinal range (to $37.7^{\circ} \mathrm{S}$ ). Climate appeared to influence the survival of individuals of two of the three morphological types (Table 1). Stilt- and knee-rooted species were most successful in temperate/subtropical regions, with extremely low survival recorded in the single study that employed kneerooted species in arid zones (Figure 4E,F and Table 1). In contrast, pencil-rooted species showed no difference in survival among climate zones.
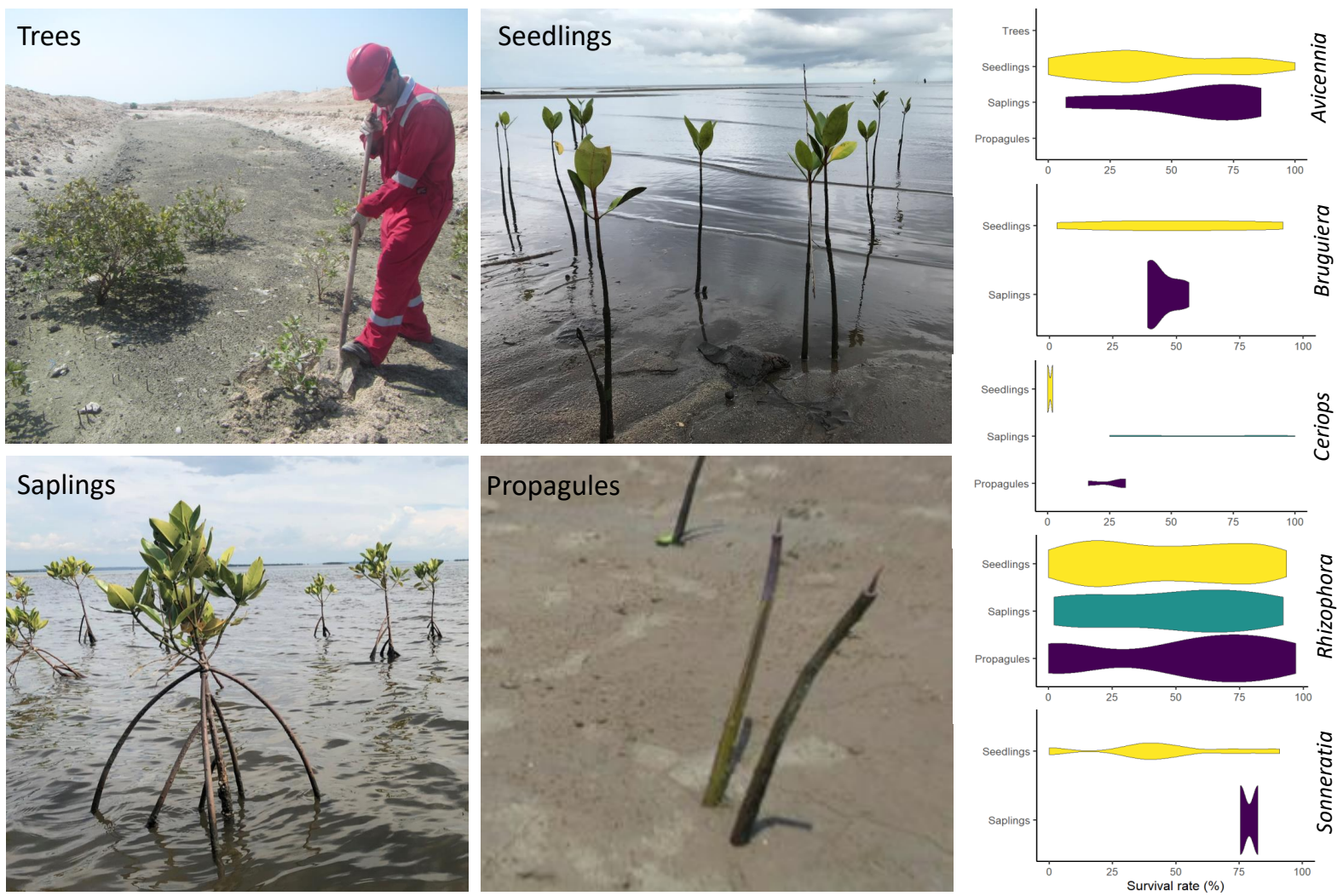

Figure 2. Violin plot showing the distribution of survival outcomes (\%) for mangrove planting projects using different life history stages, for each of the 5 main genera used. Photos by D.G., M.V. and Dr. Paul Erftemeijer.

Coastal environmental setting was a strong predictor of survival of individuals of two of the three morphological groups (Table 1). Pencil-rooted species (Avicennia and Sonneratia) yielded the highest survival within fringing habitats $(59.8 \% \pm 7.0 \%)$, followed by estuaries $(59.0 \% \pm 8.4 \%)$, lagoons $(49.7 \% \pm 5.2 \%)$ and the lowest survival in deltas $(39.0 \% \pm 4.4 \%$, Figure $4 \mathrm{~A})$. In contrast, stilt-rooted species (Rhizophora) yielded the highest survival in lagoons $(66.7 \% \pm 7.1 \%)$, followed by fringing habitats $(56.1 \% \pm 5.9 \%)$, with estuaries $(39.4 \% \pm 6.3 \%)$ and deltas $(37.9 \% \pm 4.3 \%)$ yielding lower and similar survival (Figure 4B). Knee-rooted species (Bruguiera, Ceriops and Xylocarpus) yielded high survival in deltas $(49.4 \% \pm 7.5 \%)$ and lower (but not significantly different) survival in fringing $(35.9 \% \pm 10.1 \%)$ and estuarine habitats $(35.7 \% \pm 15.2 \%)$-there were no studies of this group in lagoons. While tidal range was not a significant predictor of survival of stilt- or knee-rooted species (Figure $4 \mathrm{~K}, \mathrm{~L}$ ), increasing tidal amplitude did correlate positively with 
the survival of pencil-rooted species, although this appeared to be due to a small number of studies carried out in locations where the range exceeded $2.5 \mathrm{~m}$ (Figure 4J).

Table 1. The results of Generalized Linear Mixed Models to test the percentage survival (\%) of mangrove restoration projects, with categorical factors (life history, CES and climate) treated as fixed effects, while continuous covariates (tide and plant spacing) used cubic smoothing splines, signified with ' $s()$ '. Terms in italics were found to be not statistically significant at $p \leq 0.05$ and were removed through stepwise backward selection. SD is the standard deviation for continuous variables, SE is the standard error of the fixed effects terms and $p$ is the $p$-value for the Z-statistic.

\begin{tabular}{|c|c|c|c|c|}
\hline Source & Estimate & SD/SE & z-Value & $p$ \\
\hline \multicolumn{5}{|l|}{ Pencil roots } \\
\hline Type-seedlings & -0.52 & 0.25 & -2.10 & 0.036 \\
\hline CES-Estuary & 0.56 & 0.26 & 2.17 & 0.030 \\
\hline CES-Fringe & 0.69 & 0.22 & 3.11 & 0.002 \\
\hline CES-Lagoon & 0.52 & 0.22 & 2.37 & 0.018 \\
\hline \multicolumn{5}{|l|}{ Climate-Temperate } \\
\hline $\begin{array}{l}\text { Climate-Tropical } \\
\text { s(plant spacing) } \\
\text { s(latitude) }\end{array}$ & & & & \\
\hline s(tidal height) & 0.38 & 0.12 & 3.23 & 0.001 \\
\hline \multicolumn{5}{|l|}{ Stilt roots } \\
\hline \multicolumn{5}{|l|}{ Type-seedlings } \\
\hline CES-Estuary & -0.02 & 0.24 & -0.09 & 0.926 \\
\hline CES-Fringe & 0.59 & 0.23 & 2.58 & 0.010 \\
\hline CES-Lagoon & 0.65 & 0.30 & 2.16 & 0.031 \\
\hline Climate-Temperate & 1.68 & 0.50 & 3.36 & 0.001 \\
\hline Climate-Tropical & 1.61 & 0.49 & 3.31 & 0.001 \\
\hline s(plant spacing) & 0.47 & 0.18 & 2.70 & 0.007 \\
\hline \multicolumn{5}{|l|}{ s(latitude) } \\
\hline \multicolumn{5}{|l|}{ s(tidal height) } \\
\hline \multicolumn{5}{|l|}{ Knee roots } \\
\hline \multicolumn{5}{|l|}{ Type-seedlings } \\
\hline \multicolumn{5}{|l|}{ CES-Estuary } \\
\hline \multicolumn{5}{|l|}{ CES-Fringe } \\
\hline \multicolumn{5}{|l|}{ CES-Lagoon } \\
\hline Climate-Temperate & 3.78 & 0.96 & 3.95 & $<0.001$ \\
\hline Climate-Tropical & 3.12 & 0.92 & 3.38 & 0.001 \\
\hline \multicolumn{5}{|l|}{ s(plant spacing) } \\
\hline s(latitude) & & & & \\
\hline s(tidal height) & & & & \\
\hline
\end{tabular}

The effort devoted to raising and caring for mangroves before (i.e., nursery period) and after planting also differed for mangroves with different root morphologies, although it must be noted that very few studies reported this information (only 33\% and 36\%, respectively, across all studies). When compared to knee-rooted species which only spent an average of 6 months in a nursery prior to planting (maximum 12 months), pencil- and stiltrooted species were grown in a nursery for 9 months on average before planting (maximum 24 months). With respect to the reported provision of after-planting care, proportionally more studies reported beneficial survival outcomes for stilt-rooted species ( $41 \%$ of studies), followed by knee-rooted species (30\%) and with the lowest reported effort directed at pencilrooted species $(20 \%)$. From the data available (only $35 \%$ of all data points corresponded with this information), after-care had a significant positive effect on the success of all morphological groups, increasing the survival of individuals by $14 \%$ for knee-rooted species, $32 \%$ for stilt-rooted species and by $50 \%$ for pencil-rooted species. 


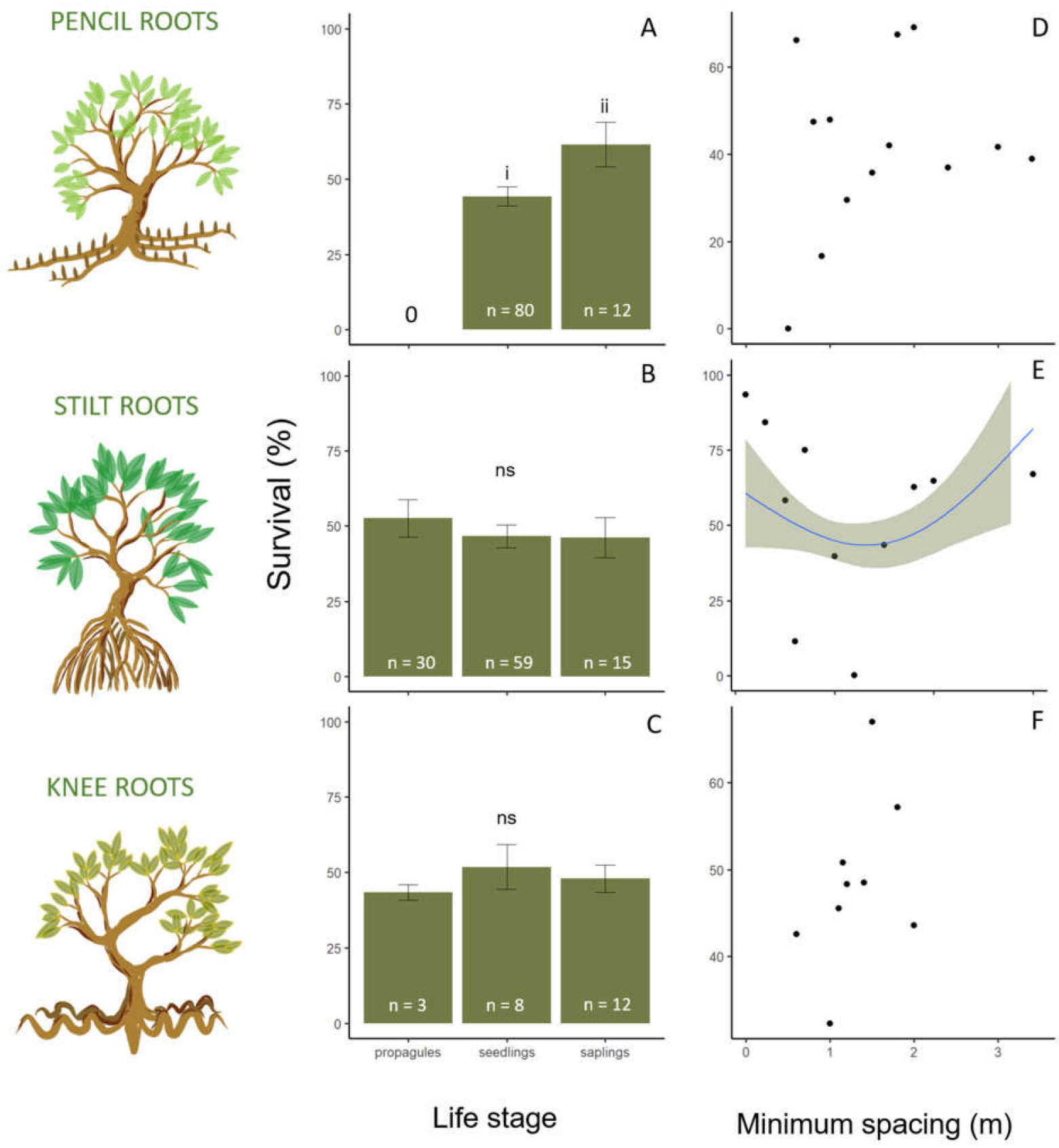

Figure 3. Influence of life stage and spacing on survival rates for mangrove planting projects involving species that have pencil roots (Avicennia and Sonneratia), stilt roots (Rhizophora) and knee roots (Bruguiera and Ceriops). Data are means \pm SE for life stage (A-C) and smooth splines (partial plots) for spacing (D-F). Different roman numerals signify statistically significant differences among fixed factors, and 'ns' = no significant difference.

The most widely reported cause of mortality for pencil-rooted species was improper site selection (54\% of studies), followed by unsuitable abiotic factors (39\%-presumably poor water quality of desiccation due to high temperatures and inadequate inundation) and predation (7\%). Stilt-rooted species experienced high mortality due to adverse abiotic factors (35\%), predators (32\%), improper site selection $(27 \%)$ and competition $(6 \%)$. Kneerooted species exhibited high mortality due to abiotic factors (43\%), competition (43\%) and predators (14\%). 


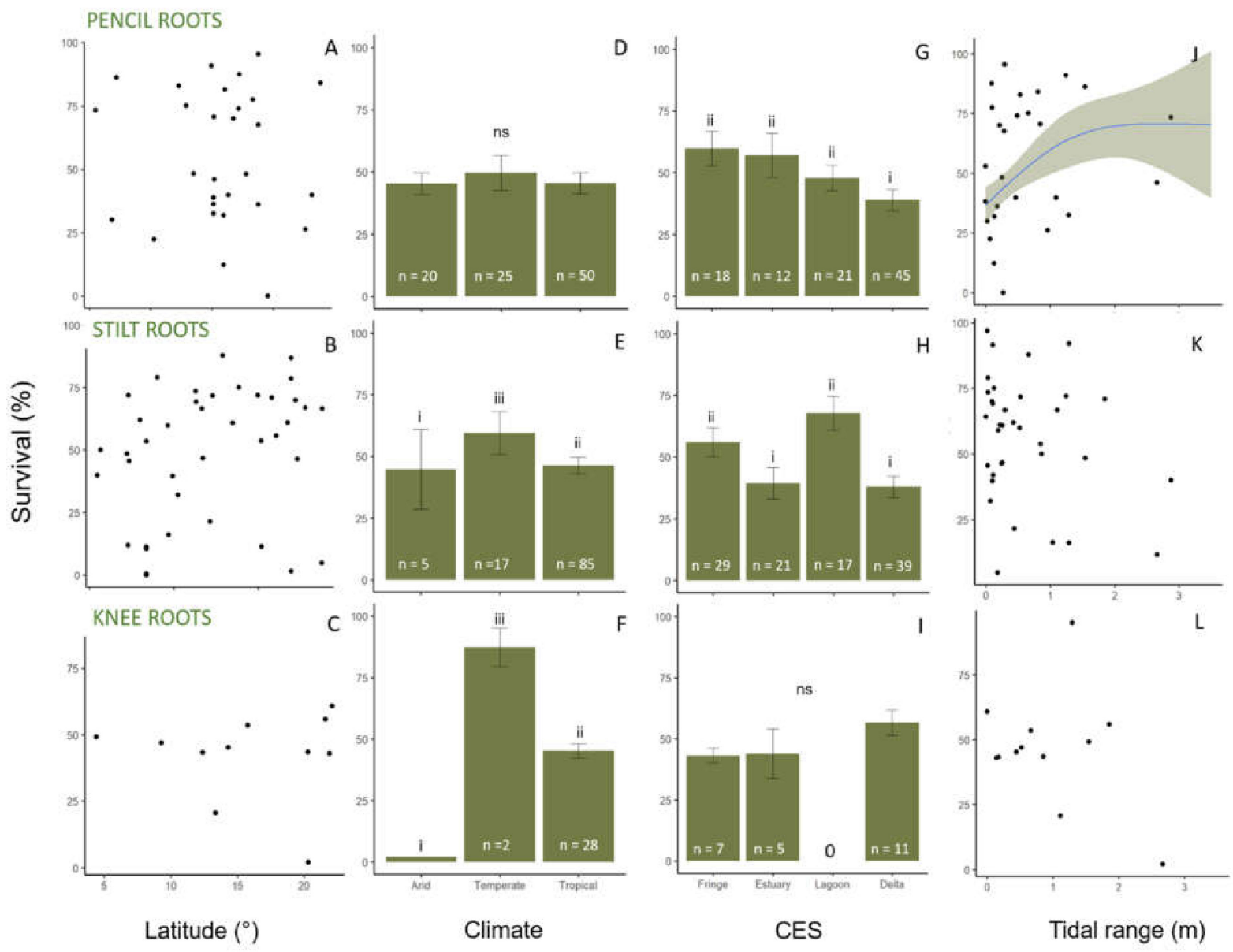

Figure 4. Influence of latitude (A-C), climate (D-F), coastal environmental setting (CES) (G-I) and tidal range $(\mathrm{J}-\mathrm{L})$ on survival rates for mangrove planting projects involving species that have pencil roots $(\mathbf{A}, \mathbf{D}, \mathbf{G}, \mathbf{J})$, stilt roots $(\mathbf{B}, \mathbf{E}, \mathbf{H}, \mathbf{K})$ and knee roots $(\mathbf{C}, \mathbf{F}, \mathbf{I}, \mathbf{L})$ (see Supplementary Table S1 for species). Data are means \pm SE for climate and CES and smooth splines (partial plots) for latitude and tidal range. Different roman numerals signify statistically significant differences among fixed factors, and 'ns' = no significant difference.

\section{Discussion}

This study presents a synthesis of information that might help to understand how mangrove planting methods can influence survival across a variety of biogeographic and environmental contexts (from tropical to temperate coastlines and encompassing multiple coastal geomorphologies). The trends identified suggest that the survival of planted individuals can be influenced by decisions about what species to plant and where to plant them, as well as climate (at the global and macro-scale) and the coastal environmental setting, which has been successfully used to improve understanding on other aspects of mangrove forest ecology such as soil carbon storage [34]. These insights can help to identify some of the physiological limits (e.g., climate reflects temperature, tidal range reflects duration of immersion), that can result in the failure of restoration programs [40]. While some influences-such as climate-are beyond the control of practitioners working within a particular region, others, such as the species used and the minimum plant spacing adopted, can be readily adjusted to maximize survival and enhance project success [20,41-43].

\subsection{Methodological Considerations to Planting}

The analysis highlights the importance of some of the fundamental methodological considerations for mangrove planting efforts, including the life stage of planted individuals, minimum spacing requirements and the perceived benefits of nursery grow out and after- 
care. The use of propagules for marine coastal restoration has emerged as an advantageous and cost-effective way of scaling-up reforestation projects, and one that is particularly relevant to mangroves [25]. Results highlight that survival can be greatly influenced by the life stage planted, but that this might be more pronounced for certain morphological groups of mangroves. While there were differences in the survival of seedlings and saplings for pencil-rooted species (the latter showing 17\% higher survival on average than the former), there was no comparable effect for stilt-rooted or knee-rooted species.

Higher survival of saplings than seedlings is recognized in terrestrial forestry [44], and the analysis suggests that this may also be the case for some of the most frequently planted mangrove taxa, including Avicennia spp. and Sonneratia spp. Indeed, previous studies involving Avicennia marina have shown that larger transplanted seedlings survive better than or equal to medium-sized individuals and exhibit greater increases in plant height and leaf production than small individuals [45]. Saplings, being the largest life stage typically used in mangrove restoration projects (except for the few studies that have employed adult trees [31]), appear more able to withstand higher exposure to waves and wind that often characterize fringing habitats [23]. It is interesting to note that there were no reported studies using the less-developed propagules of pencil-rooted mangroves (i.e., seed capsules or fruits), although it remains unclear as to whether this is due to recording bias or whether this is due to experience learned by practitioners. It is possible that this might be the result of disproportionately high rates of predation by crabs [46] or simply because practitioners have found this approach not to be viable for these types of mangroves (e.g., because of seed dormancy [47]). While not statistically significant in our analysis, the high rates of survival for stilt-rooted species planted as propagules might suggest that this approach may be more efficient and that the additional effort of growing these species in a nursery may not be warranted [25]. This may especially be the case in certain developed countries where the costs of labor are comparatively high [48], or in places such as Bangladesh where the aim is to stabilize accreting shores [49].

The review of available data suggests that most mangrove planting projects (both restoration and afforestation) around the world employ spacing configurations that are less than $3.5 \mathrm{~m}$ between plants (most commonly 1-2 m). There were few exceptions, with only one project involving spacings of up to $3.4 \times 3.4 \mathrm{~m}$ (i.e., $12 \mathrm{~m}^{2}$ [12]). Here, again, the wider spacings used in plantings of species such as Sonneratia spp. probably reflect specific applications of afforestation for rapidly accreting sediments in places such as Bangladesh [50], reflecting a desire to cover as extensive an area as possible to protect vulnerable coastlines from flooding and cyclones [51].

Results showed that the survival of only stilt-rooted species (e.g., Rhizophora) appears to be influenced by plant spacing (and by extension the density of individuals). After an initial decline in the survival of individuals planted $0.5-1.5 \mathrm{~m}$ apart, survival improved at larger minimum spacings. This result matches a study that evaluated the root density growth of Rhizophora mucronata in northern Sumatra over one year to suggest an optimum plant spacing distance of $3 \mathrm{~m} \times 2 \mathrm{~m}$ [52]. Part of the reason for the lower growth rates of densely spaced Rhizophora spp. may be due to their relatively low competitive ability both with conspecifics (monoculture) and when compared against other groups such as Laguncularia spp. as mixed cultures [53]. Alternatively, the high survival of smaller spacing arrangements (i.e., minimum spacing of less than $0.5 \mathrm{~m}$ ) may be an artefact of the high representation of experimental studies that are performed for purposes other than restoration [54,55]. Intensively managed, small-scale experimental studies might facilitate higher survival than large-scale restoration or afforestation efforts where scale and resources do not permit sufficient after-care (see considerations and critiques of the concept of 'ecological validity' [56,57]).

Understanding the importance of planting methods with some of the more intangible aspects of plant husbandry such as after-care is an interesting challenge and one that should be considered in any restoration program. Relatively few studies have provided details on the duration of nursery periods (e.g., only $33 \%$ of all studies), stated whether there was 
any degree of after-care (only $36 \%$ of studies) or interpreted the main reasons for mortality (only $47 \%$ of studies). Although this limited our ability to conduct statistical analysis, the qualitative data are revealing and provide insights into the causes of success or failure. Of particular interest is the effect of after-care, which appeared to facilitate higher survival of individuals from all morphological groups, increasing survival rates by $14 \%$ for knee-rooted species, $32 \%$ for stilt-rooted species and by $50 \%$ for pencil-rooted species. Similar results were gleaned from the few studies that reported on the main causes of mortality. Across all three mangrove groups, unsuitable abiotic factors were listed as the most common cause of mortality (responsible for $41 \%$ of failures), followed by inappropriate abiotic conditions (39\%), competition (26\%, although this did not include pencil-rooted species) and predators (18\%). This information might help practitioners to consider the variables that most influence the survival of planted individuals (and therefore the subsequent success of restoration projects).

\subsection{Environmental Influences}

The importance of climate and the environment are well-established influences on forest structure and function in marine [58,59] and terrestrial systems [60]. Global-scale proxies such as climate as well as local context such as coastal setting and tidal range also appear to influence the survival of individuals of all different morphological groups of mangroves. Climate was correlated with survival of both stilt- and knee-rooted species but was not associated with any trends in survival of pencil-rooted species. Surprisingly, latitude, while often used as a proxy for mangrove forest productivity, diversity and forest structure at a global scale $[2,61]$, was not a significant correlate of survival for any of the three morphological groups. In contrast, the coastal setting (pencil- and stilt-rooted species) and tidal range (pencil-rooted species) had more pronounced effects.

The failure of mangrove restoration projects is often related to the high susceptibility of propagules, seedlings and saplings to wind and wave erosion, as well as flooding and desiccation [21,40]. Repeated failures often occur when practitioners do not understand the physiological limits of different species, including planting them on bare mudflats or adjacent seagrass meadows where the soil characteristics are not compatible [20,21,40]. The results of analyses suggest that pencil-rooted species which survive well in fringing, estuarine and lagoon environments, do not fare as well in more sheltered and sedimentary environments such as deltas. In contrast, for stilt-rooted species, survival was the greatest within lagoons and fringing environments, and was significantly lower in estuaries and deltas. These specific patterns likely reflect the stability and soil characteristics of these areas, as well as the frequency and intensity of disturbances such as strong waves. Species with knee roots that typically occur in higher intertidal environments [62] did not show consistent trends (probably owing to a low sample size) but did show the highest survival outcomes in deltas.

The outcomes of restoration can vary widely over relatively short distances (e.g., hundreds of meters) where there is a pronounced environmental gradient, such as wave exposure or sedimentation [30]. Fringing coasts are exposed to stronger wind and waves and survival is expected to be greater for more tolerant pencil-rooted species that predominate within this coastal setting (Avicennia spp. [63]). For these species, there can also be important positive feedback effects, whereby the pneumatophores of adult mangroves can increase the survival of mangrove seedlings and therefore enhance recovery after disturbance [64]. Dissipation of wave energy into mangrove forests does not occur in a linear fashion and may only drop below lethal values for some seedlings within denser Rhizophora-dominated zones [65]. This explains why previous work often describes a greater survival of Rhizophora apiculata planted into softer soils [66]. By understanding the microclimate characteristics of the coastal environmental setting (and its implications for mangrove survival and growth), we might be able to improve decisions about which species to plant in different settings. Indeed, by using CES, Rovai et al. [34] were able to account for $60 \%$ of the variability in soil 
carbon estimates of mangrove forests globally and provide estimates for 57 nations that lacked this data $[67,68]$.

Many mangrove restoration projects around the globe have failed because they have not accounted for hydrological conditions [21]. Indeed, the data emphasize the important but often contrasting role of hydrology for certain species in response to the variation in the tidal range. One study of the settlement dynamics of three mangrove species [69] showed that propagules established best in the lower intertidal, where they remained partially submerged during low tides, and established more poorly in the upper intertidal. In terms of active restoration, planting mangroves in the wrong place has been shown to lead to dead, dying or "dismally stunted" trees [22]. For species with pencil roots (pneumatophores), the data suggest that survival increased from microtidal (i.e., generally considered less than $2 \mathrm{~m}$ ) to macrotidal regimes. Several previous studies have shown that the root tissue mass and oxygen content of Avicenna spp. can be influenced by the frequency and duration of inundation, showing the greatest values at intermediate durations (1.5 to $6.5 \mathrm{~h}$ per tide), which can constitute a physiological limit for this species [70,71]. This points to the need to restore hydrology (i.e., water levels) at many sites to improve natural regeneration or to plant mangrove species that are likely to survive in the altered conditions [21]. This may be particularly important where coastlines have been severely modified through the construction of shrimp farms (e.g., throughout much of south-east Asia and South America $[8,72]$ ). The outcomes of active mangrove restoration (including planted mangroves and those that regenerate following the reintroduction of tides) are similar to naturally regenerated mangroves, but sometimes lower than natural mangroves [55]. In situations where planting is necessary or desirable, improved decisions about which species to plant in different contexts should help to overcome several of the principal causes of mortality.

\subsection{Optimized Planting}

The data suggest that to improve the survival of planted mangroves, practitioners should consider beneficial plant husbandry methods such as longer nursery periods and supplemental watering [73], and carefully select which species are appropriate for the desired context, considering aspects such as climate, setting and position relative to tides. Restoring forests in temperate and subtropical regions might be improved by using wellestablished (larger) saplings (Supplementary Figure S1) of hardy species such as Avicennia marina, which has a latitudinal limit greater than the plantings reported in this present meta-analysis [74]. Survival of stilt-rooted species such as Rhizophora in deltas and estuaries of tropical regions might be improved by ensuring plants are not placed too close together $[20,75,76]$. Summarizing this data, we present a restoration guideline which could help restoration practitioners to identify patterns for formal hypotheses testing and which could ultimately help to optimize survival outcomes for different morphological groups of mangroves (Figure 5).

Only a few publications were found that reported the results of mixed species plantings [55]. Of these, survival tended to be greater within estuarine or deltaic settings (reported average $75 \%$ [77]) than in fringing settings (41\% [78,79]). The emerging shift toward multi-species planting is likely to raise further questions, including how different species perform inside and outside of existing stands of adult trees [80] and how to measure the growth performance of seedlings and saplings [81,82]. Protocols should be developed to give practitioners information on the best practice regarding timing (e.g., months, years, etc.) and methods (e.g., stem height, diameter, etc.) to improve restoration programs across different coastal systems and regions. Another consideration in the context of restoration outcomes is how survival may be influenced by the age of the forest. High rates of juvenile mortality might mean that short-duration studies show lower relative success, when compared to longer-term studies where the endpoint is mature trees [83]. Unfortunately, there was not sufficient data to evaluate changes in survival over time. Overall, this type of additional information will complement global-scale mangrove studies, providing open 
and transparent data to increase the update and impact of large-scale mangrove research and conservation [84].

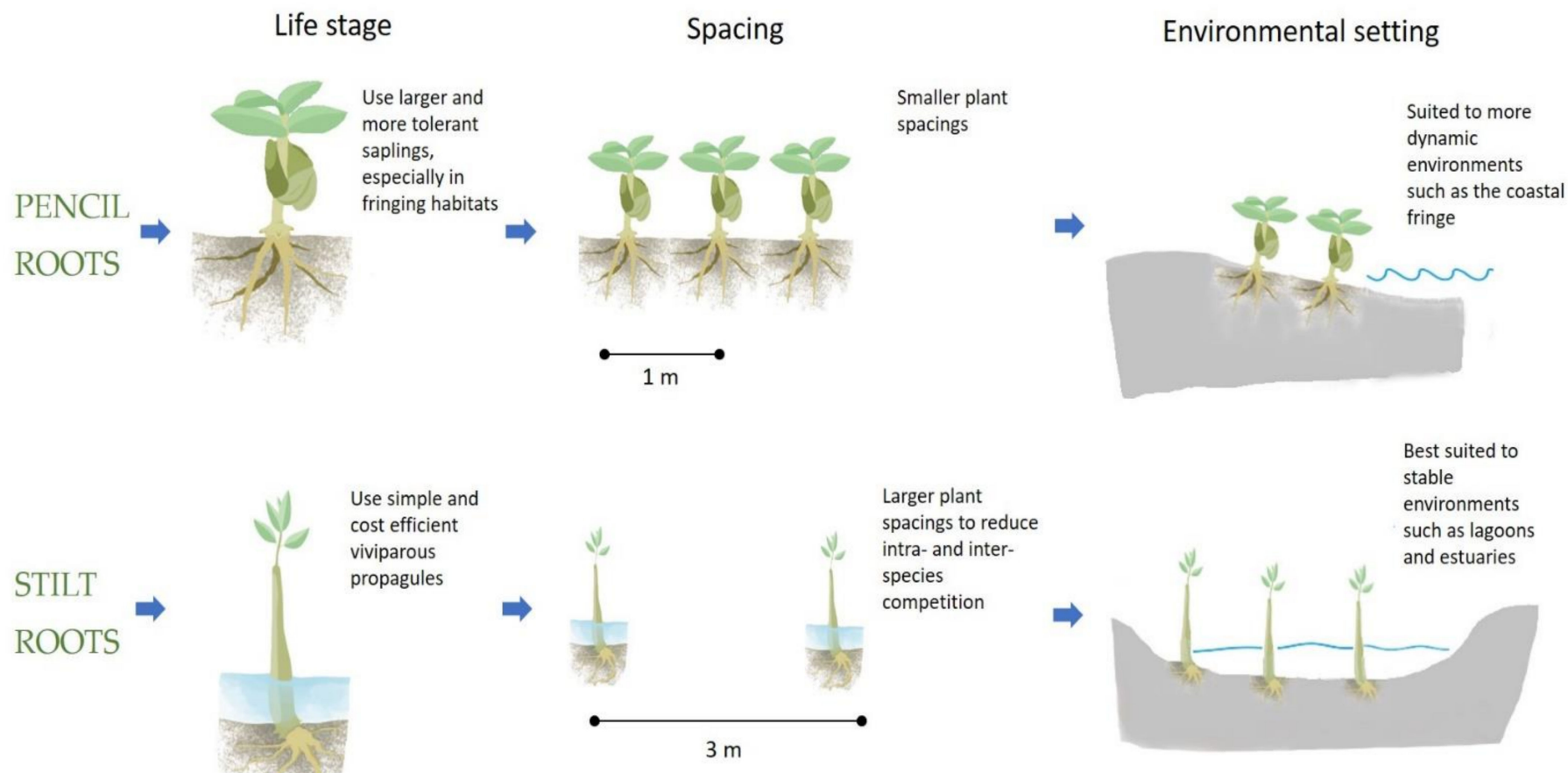

Figure 5. Restoration guidelines that can optimize survival outcomes for different morphological groups of mangroves.

\subsection{Study Strengths and Disadvantages}

The strength of the present study is that it synthesizes a diverse range of projects to extract valuable information about the survival of planted mangroves as a result of different plant husbandry methods and environmental factors. To date, few studies have tried to gather such information and use it to derive hypotheses for proper experimental tests that could help restoration practitioners. In contrast, the study also highlights some of the disadvantages of these types of meta-analyses, which can be hampered by the different metrics to measure survival, different timescales over which studies were performed and the fact that many of the technical aspects of planting methods and the background environment are rarely provided for individual studies, making it difficult to compare success across time and space. Researchers and practitioners often have different objectives, but working together should prove a fruitful way to gather information about restoration methods (e.g., life history stage and nursery stock size, the level of after-care and causes of mortality) that can be used to improve restoration outcomes.

\section{Conclusions}

Understanding the influence of planting methods and the environment on the survival of planted mangroves in a way that provides useful guidance to practitioners remains a challenge because of the complexities of local context, project goals and the suite of species available. Rather than proposing rigid protocols (as some guidelines suggest), it is recommended that practitioners consider the composition and distribution of existing intact mangrove stands in the vicinity, if possible. Overall, the findings of this review suggest that experimental tests of the effect of spacing, life stage and coastal environmental setting would be valuable to further understand the major influences on survival, and thus improve the success of mangrove planting programs globally. 


\begin{abstract}
Supplementary Materials: The following supporting information can be downloaded at: https: / / www.mdpi.com/article/10.3390/f13030404/s1, Figure S1: Selection and standardization of data used in the meta-analysis and subsequent interpretation of mangrove survival trends for mangrove species with different root morphologies; Figure S2: Spatial representation of different Coastal Environmental Settings (CES) used in analysis of survival of restored mangroves with different root morphologies; Table S1: Mangrove genera classified into different root morphologies analyzed in this review; Table S2: Number of recorded from studies (by country) including in the meta-analysis conducted in this review.
\end{abstract}

Author Contributions: D.G.: conceptualization, methodology, statistical analysis, writing-original draft; M.A.V.: conceptualization, resources, writing—review and editing, project administration; A.L.: conceptualization, investigation, meta-analysis, statistical analysis, validation, data curation, writingreview and editing. All authors have read and agreed to the published version of the manuscript.

Funding: This research was funded by the Australian Government-Department of Foreign Affairs and Trade (DFAT) — through the Australia-Sri Lanka blue carbon initiative (D19/617992), the IORA-Indian Ocean Blue Carbon Hub, and the Commonwealth Scientific and Industrial Research Organisation (CSIRO) - Coasts Program. The impetus for this work was a desire to help mangrove restoration practitioners improve outcomes across a range of contexts.

Institutional Review Board Statement: Not applicable.

Informed Consent Statement: Not applicable.

Data Availability Statement: The data presented in this study are available on request from the corresponding author.

Conflicts of Interest: The authors declare no conflict of interest.

\title{
References
}

1. Donato, D.C.; Kauffman, J.B.; Murdiyarso, D.; Kurnianto, S.; Stidham, M.; Kanninen, M. Mangroves among the most carbon-rich forests in the tropics. Nat. Geosci. 2011, 4, 293-297. [CrossRef]

2. Giri, C.; Ochieng, E.; Tieszen, L.L.; Zhu, Z.; Singh, A.; Loveland, T.; Masek, J.; Duke, N. Status and distribution of mangrove forests of the world using earth observation satellite data. Glob. Ecol. Biogeogr. 2011, 20, 154-159. [CrossRef]

3. Alongi, D.M. Carbon sequestration in mangrove forests. Carbon Manag. 2012, 3, 313-322. [CrossRef]

4. Alongi, D.M. Mangrove forests: Resilience, protection from tsunamis, and responses to global climate change. Estuar. Coast. Shelf Sci. 2008, 76, 1-13. [CrossRef]

5. McLeod, E.; Chmura, G.L.; Bouillon, S.; Salm, R.; Bjork, M.; Duarte, C.M.; Lovelock, C.E.; Schlesinger, W.H.; Silliman, B.R. A blueprint for blue carbon: Toward an improved understanding of the role of vegetated coastal habitats in sequestering $\mathrm{CO}_{2}$. Front. Ecol. Environ. 2011, 9, 552-560. [CrossRef]

6. Hamilton, S.E.; Casey, D. Creation of a high spatio-temporal resolution global database of continuous mangrove forest cover for the 21st century (CGMFC-21). Glob. Ecol. Biogeogr. 2016, 25, 729-738. [CrossRef]

7. Alongi, D.M. Present state and future of the world's mangrove forests. Environ. Conserv. 2002, 29, 331-349. [CrossRef]

8. Gorman, D. Historical losses of mangrove systems in South America from both human-induced and natural impacts. In Threats to Mangrove Forests: Hazards, Vulnerability, and Management; Makowski, C., Ed.; Coastal Research Library; Springer: Berlin/Heidelberg, Germany, 2018.

9. $\quad$ Friess, D.A.; Rogers, K.; Lovelock, C.E.; Krauss, K.W.; Hamilton, S.E.; Lee, S.Y.; Lucas, R.; Primavera, J.; Rajkaran, A.; Shi, S. The State of the World's Mangrove Forests: Past, Present, and Future. Annu. Rev. Environ. Resour. 2019, 44, 89-115. [CrossRef]

10. FAO (Food and Agriculture Organization of the United Nations). The World's Mangroves 1980-2005; FAO Forestry Paper; FAO: Rome, Italy, 2007.

11. Polidoro, B.A.; Carpenter, K.E.; Collins, L.; Duke, N.C.; Ellison, A.M.; Ellison, J.C.; Farnsworth, E.J.; Fernando, E.S.; Kathiresan, K.; Koedam, N.E.; et al. The Loss of Species: Mangrove Extinction Risk and Geographic Areas of Global Concern. PLoS ONE 2010, 5 , e10095. [CrossRef]

12. Ellison, A.M.; Felson, A.J.; Friess, D.A. Mangrove Rehabilitation and Restoration as Experimental Adaptive Management. Front. Mar. Sci. 2020, 7, 327. [CrossRef]

13. Richards, D.R.; Friess, D.A. Rates and drivers of mangrove deforestation in Southeast Asia, 2000-2012. Proc. Natl. Acad. Sci. USA 2016, 113, 344-349. [CrossRef]

14. Howard, R.J.; Day, R.H.; Krauss, K.W.; From, A.S.; Allain, L.; Cormier, N. Hydrologic restoration in a dynamic subtropical mangrove-to-marsh ecotone. Restor. Ecol. 2017, 25, 471-482. [CrossRef]

15. FAO. Mangrove Forest Management Guidelines; Food and Agriculture Organization of the United Nations: Rome, Italy, 1994. 
16. Saenger, P.; Siddiqi, N.A. Land from the sea-The mangrove afforestation program of Bangladesh. Ocean. Coast. Manag. 1993, 20, 23-39. [CrossRef]

17. Kroeger, K.D.; Crooks, S.; Moseman-Valtierra, S.; Tang, J. Restoring tides to reduce methane emissions in impounded wetlands: A new and potent Blue Carbon climate change intervention. Sci. Rep. 2017, 7, 11914. [CrossRef]

18. Hong, P.N. Restoration of mangrove ecosystems in Vietnam: A case study of Can Gio District, Ho Chi Minh City. In Restoration of Mangrove Ecosystems; Field, C., Ed.; International Society for Mangrove Ecosystems and International Tropical Timber Organization (ITTO): Okinawa, Japan, 1996; pp. 76-79.

19. Lewis, R.R. Ecological engineering for successful management and restoration of mangrove forests. Ecol. Eng. 2005, 24, 403-418. [CrossRef]

20. UNEP, N.C.U.W. Guidelines on Mangrove Ecosystem Restoration for the Western Indian Ocean Region; UNEP: Nairobi, Kenya, 2020; p. 71.

21. Van Loon, A.F.; te Brake, B.; van Huijgevoort, M.H.J.; Dijksma, R. Hydrological Classification, a Practical Tool for Mangrove Restoration. PLoS ONE 2016, 11, e0150302. [CrossRef]

22. Samson, M.S.; Rollon, R.N. Growth performance of planted mangroves in the Philippines: Revisiting forest management strategies. Ambio 2008, 37, 234-240. [CrossRef]

23. Gorman, D.; Turra, A. The role of mangrove revegetation as a means of restoring macrofaunal community structure along subtropical coasts. Sci. Total Environ. 2016, 566, 223-229. [CrossRef]

24. Blum, J.; Herr, D. Mass Mangrove Restoration: Driven by Good Intentions but Offering Limited Results; IUCN: Gland, Switzerland, 2017.

25. Vanderklift, M.A.; Doropoulos, C.; Gorman, D.; Leal, I.; Minne, A.J.P.; Statton, J.; Steven, A.D.L.; Wernberg, T. Using Propagules to Restore Coastal Marine Ecosystems. Front. Mar. Sci. 2020, 7, 724. [CrossRef]

26. Fickert, T. To Plant or Not to Plant, That Is the Question: Reforestation vs. Natural Regeneration of Hurricane-Disturbed Mangrove Forests in Guanaja (Honduras). Forests 2020, 11, 1068. [CrossRef]

27. Saunders, M.I.; Doropoulos, C.; Bayraktarov, E.; Babcock, R.C.; Gorman, D.; Eger, A.M.; Vozzo, M.L.; Gillies, C.L.; Vanderklift, M.A.; Steven, A.D.L.; et al. Bright Spots in Coastal Marine Ecosystem Restoration. Curr. Biol. 2020, 30, R1500-R1510. [CrossRef]

28. Sigi Lang'at, K.; Kirui, B.; Skov, M.; Kairo, J.G.; Mencuccini, M.; Huxham, M. Species mixing boosts root yield in mangrove trees. Oecologia 2012, 172, 271-278. [CrossRef]

29. Göltenboth, F.; Schoppe, S. 10-Mangroves. In Ecology of Insular Southeast Asia; Göltenboth, F., Timotius, K.H., Milan, P.P., Margraf, J., Eds.; Elsevier: Amsterdam, The Netherlands, 2006; pp. 187-214.

30. Gorman, D.; Turra, A. Mangrove revegetation as a means of restoring macrofaunal communities along degraded coasts. In Proceedings of the ECSA 57 Changing Estuaries, Coasts and Shelf Systems-Diverse Threats and Opportunities, Perth, Australia, 3-6 September 2018.

31. Erftemeijer, P.L.A.; Price, B.A.; Ito, S.; Yamamoto, H.; Agastian, T.; Cambridge, M.L. Salvaging and replanting 300 mangrove trees and saplings in the arid Arabian Gulf. Mar. Freshw. Res. 2021, 72, 1577-1587. [CrossRef]

32. Basher, Z.; Costello, M.J.; Bowden, D.A. Global Marine Environment Dataset (GMED). World Wide Web Electronic Publication Version 1.0. 2014. Available online: http:/ / gmed.auckland.ac.nz (accessed on 18 December 2020).

33. Peel, M.C.; Finlayson, B.L.; McMahon, T.A. Updated world map of the Köppen-Geiger climate classification. Hydrol. Earth Syst. Sci. 2007, 11, 1633-1644. [CrossRef]

34. Wood, S.N. Generalized Additive Models: An Introduction with R; CRC: Boca Raton, FL, USA, 2006

35. R Development Core Team. R: A Language and Environment for Statistical Computing; R Foundation for Statistical Computing: Vienna, Austria, 2011; Available online: http:/ / www.R-project.org (accessed on 18 January 2020).

36. Wood, S.N.; Augustin, N.H. GAMs with integrated model selection using penalized regression splines and applications to environmental modelling. Ecol. Model. 2002, 157, 157-177. [CrossRef]

37. Austin, M.P.; van Niel, K.P. Impact of landscape predictors on climate change modelling of species distributions: A case study with Eucalyptus fastigata in southern New South Wales, Australia. J. Biogeogr. 2011, 38, 9-19. [CrossRef]

38. Zuur, A.F.; Ieno, E.N.; Walker, N.; Saveliev, A.A.; Smith, G.M. Mixed Effects Models and Extensions in Ecology with R; Springer: Berlin/Heidelberg, Germany, 2009.

39. Rovai, A.S.; Twilley, R.R.; Castaneda-Moya, E.; Riul, P.; Cifuentes-Jara, M.; Manrow-Villalobos, M.; Horta, P.A.; Simonassi, J.C.; Fonseca, A.L.; Pagliosa, P.R. Global controls on carbon storage in mangrove soils. Nat. Clim. Chang. 2018, 8, 534. [CrossRef]

40. Kodikara, K.A.S.; Mukherjee, N.; Jayatissa, L.P.; Dahdouh-Guebas, F.; Koedam, N. Have mangrove restoration projects worked? An in-depth study in Sri Lanka. Restor. Ecol. 2017, 25, 705-716. [CrossRef]

41. ICRI. Mangrove Restoration: Summary of the Key Elements to be Considered in any Restoration Project; ICRI: Nairobi, Kenya, 2018.

42. Duarte, C.M.; Agusti, S.; Barbier, E.; Britten, G.L.; Castilla, J.C.; Gattuso, J.-P.; Fulweiler, R.W.; Hughes, T.P.; Knowlton, N.; Lovelock, C.E.; et al. Rebuilding marine life. Nature 2020, 580, 39-51. [CrossRef]

43. Waltham, N.J.; Elliott, M.; Lee, S.Y.; Lovelock, C.; Duarte, C.M.; Buelow, C.; Simenstad, C.; Nagelkerken, I.; Claassens, L.; Wen, C.K.-C.; et al. UN Decade on Ecosystem Restoration 2021-2030-What Chance for Success in Restoring Coastal Ecosystems? Front. Mar. Sci. 2020, 7, 71. [CrossRef]

44. Good, N.F.; Good, R.E. Population Dynamics of Tree Seedlings and Saplings in a Mature Eastern Hardwood Forest. Bull. Torrey Bot. Club 1972, 99, 172-178. [CrossRef] 
45. Osunkoya, O.O.; Creese, R.G. Population structure, spatial pattern and seedling establishment of the grey mangrove, Avicennia marina var. australasica, in New Zealand. Aust. J. Bot. 1997, 45, 707-725.

46. Smith, T.J.; Chan, H.T.; McIvor, C.C.; Robblee, M.B. Comparisons of Seed Predation in Tropical, Tidal Forests from Three Continents. Ecology 1989, 70, 146-151. [CrossRef]

47. Purnobasuki, H.; Utami, E. Seed germination of Avicennia marina (Forsk.) Vierh. by pericarp removal treatment. Biotropia 2017, 23, 75-84.

48. Bayraktarov, E.; Saunders, M.I.; Abdullah, S.; Mills, M.; Beher, J.; Possingham, H.P.; Mumby, P.J.; Lovelock, C.E. The cost and feasibility of marine coastal restoration. Ecol. Appl. 2016, 26, 1055-1074. [CrossRef]

49. Uddin, M.; Mahmud, M. Impacts of Mangrove Plantations on Land Stabilization Along the Coastline in Bangladesh. Am. J. Earth Environ. Sci. 2019, 2, 1-8.

50. Gijón Mancheño, A.; Herman, P.M.J.; Jonkman, S.N.; Kazi, S.; Urrutia, I.; van Ledden, M. Mapping Mangrove Opportunities with Open Access Data: A Case Study for Bangladesh. Sustainability 2021, 13, 8212. [CrossRef]

51. Iftekhar, S.; Islam, M. Managing mangroves in Bangladesh: A strategy analysis. J. Coast. Conserv. 2004, 10, 139-146. [CrossRef]

52. Basyuni, M.; Miharza, T.; Sinulingga, E.K.; Gultom, E.N.; Bimantara, Y.; Yunasfi. Effect of paranet shade on the growth and morphological characteristics in six mangrove seedlings. IOP Conf. Ser. Earth Environ. Sci. 2020, 452, 012090. [CrossRef]

53. Cardona-Olarte, P.; Twilley, R.R.; Krauss, K.W.; Rivera-Monroy, V. Responses of neotropical mangrove seedlings grown in monoculture and mixed culture under treatments of hydroperiod and salinity. Hydrobiologia 2006, 569, 325-341. [CrossRef]

54. Bayraktarov, E.; Brisbane, S.; Hagger, V.; Smith, C.S.; Wilson, K.A.; Lovelock, C.E.; Gillies, C.; Steven, A.D.L.; Saunders, M.I. Priorities and Motivations of Marine Coastal Restoration Research. Front. Mar. Sci. 2020, 7, 484. [CrossRef]

55. Su, J.; Friess, D.A.; Gasparatos, A. A meta-analysis of the ecological and economic outcomes of mangrove restoration. Nat. Commun. 2021, 12, 5050. [CrossRef]

56. Holleman, G.A.; Hooge, I.T.C.; Kemner, C.; Hessels, R.S. The 'Real-World Approach' and Its Problems: A Critique of the Term Ecological Validity. Front. Psychol. 2020, 11, 721. [CrossRef]

57. Cairns, J. Setting ecological restoration goals for technical feasibility and scientific validity. Ecol. Eng. 2000, 15, 171-180. [CrossRef]

58. Simonetta, F.; Antonio, T.; Lisandro, B.-C. Patterns of distribution of marine assemblages from rocky shores: Evidence of relevant scales of variation. Mar. Ecol. Prog. Ser. 2005, 296, 13-29.

59. Fowler-Walker, M.; Connell, S.; Gillanders, B. Variation at local scales need not impede tests for broader scale patterns. Mar. Biol. 2005, 147, 823-831. [CrossRef]

60. Bogdziewicz, M.; Hacket-Pain, A.; Ascoli, D.; Szymkowiak, J. Environmental variation drives continental scale synchrony of European beech reproduction. Ecology 2021, 102, e03384. [CrossRef]

61. Mazumder, D.; Saintilan, N.; Yusoff, F.M.; Kelleway, J.J. Equivalence of trophic structure between a tropical and temperate mangrove ecosystem in the Indo-Pacific. Mar. Freshw. Res. 2019, 70, 1436-1444. [CrossRef]

62. Burger, B. Wave Attenuation in Mangrove Forests: Numerical Modelling of Wave Attenuation by Implementation of a Physical Description of Vegetation in SWAN; Delft University of Technology: Delft, The Netherlands, 2005.

63. Ward, R.D.; Friess, D.A.; Day, R.H.; MacKenzie, R.A. Impacts of climate change on mangrove ecosystems: A region-by-region overview. Ecosyst. Health Sustain. 2016, 4, e01211. [CrossRef]

64. Huisman, T.J.; van Langevelde, F.; de Boer, W.F. Local positive feedback and the persistence and recovery of fringe Avicennia marina (Forssk.) vierh. mangroves. Wetl. Ecol. Manag. 2009, 17, 601-611. [CrossRef]

65. Balke, T.; Bouma, T.J.; Herman, P.M.J.; Horstman, E.M.; Sudtongkong, C.; Webb, E.L. Cross-shore gradients of physical disturbance in mangroves: Implications for seedling establishment. Biogeosciences 2013, 10, 5411-5419. [CrossRef]

66. Komiyama, A.; Santiean, T.; Higo, M.; Patanaponpaiboon, P.; Kongsangchai, J.; Ogino, K. Microtopography, soil hardness and survival of mangrove (Rhizophora apiculata BL) seedlings planted in an abandoned tin-mining area. For. Ecol. Manag. 1996, 81, 243-248. [CrossRef]

67. Worthington, T.; Spalding, M. Mangrove Restoration Potential a Global Map Highlighting a Critical Opportunity; University of Cambridge: Cambridge, UK, 2019.

68. Hu, W.; Wang, Y.; Zhang, D.; Yu, W.; Chen, G.; Xie, T.; Liu, Z.; Ma, Z.; Du, J.; Chao, B.; et al. Mapping the potential of mangrove forest restoration based on species distribution models: A case study in China. Sci. Total Environ. 2020, 748, 142321. [CrossRef]

69. Sousa, W.P.; Kennedy, P.G.; Mitchell, B.J.; Ordonez, B.M. Supply-side ecology in mangroves: Do propagule dispersal and seedling establishment explain forest structure? Ecol. Monogr. 2007, 77, 53-76. [CrossRef]

70. Hovenden, M.J.; Curran, M.; Cole, M.A.; Goulter, P.F.E.; Skelton, N.J.; Allaway, W.G. Ventilation and respiration in roots of one-year-old seedlings of grey mangrove Avicennia marina (Forsk) Vierh. Hydrobiologia 1995, 295, 23-29. [CrossRef]

71. Skelton, N.J.; Allaway, W.G. Oxygen and pressure changes measured in situ during flooding in roots of the grey mangrove Avicennia marina (Forssk) Vierh. Aquat. Bot. 1996, 54, 165-175. [CrossRef]

72. Friess, D.A.; Thompson, B.S.; Brown, B.; Amir, A.A.; Cameron, C.; Koldewey, H.J.; Sasmito, S.D.; Sidik, F. Policy challenges and approaches for the conservation of mangrove forests in Southeast Asia. Conserv. Biol. 2016, 30, 933-949. [CrossRef]

73. Toledo, G.; Rojas, A.; Bashan, Y. Monitoring of black mangrove restoration with nursery-reared seedlings on an arid coastal lagoon. Hydrobiologia 2001, 444, 101-109. [CrossRef]

74. Duke, N.C. Phenological trends with latitude in the mangrove tree Avicennia marina. J. Ecol. 1990, 78, 113-133. [CrossRef] 
75. Gulayan, S.J.; Aaron-Amper, J.; Handugan, E.R.B. Mangrove rehabilitation using Rhizophora sp. in Northeastern Bohol, Philippines. Int. J. Environ. Rural. Dev. 2015, 6, 63-68.

76. Brown, B.; Fadillah, R.; Nurdin, Y.; Soulsby, I.; Ahmad, R. Case Study: Community Based Ecological Mangrove Rehabilitation (CBEMR) in Indonesia. SAPIENS 7. 2014. Available online: https://wwws.openedition.org/sapiens/1589 (accessed on 18 December 2020).

77. Gilman, E.; Ellison, J. Efficacy of alternative low-cost approaches to mangrove restoration, American Samoa. Estuaries Coasts 2007, 30, 641-651. [CrossRef]

78. Macintosh, D.; Ashton, E.; Havanon, S. Mangrove Rehabilitation and Intertidal Biodiversity: A Study in the Ranong Mangrove Ecosystem, Thailand. Estuar. Coasts Shelf Sci. 2002, 55, 331-345. [CrossRef]

79. Soemodihardjo, S.; Wiroatmodjo, P.; Mulia, F.; Harahap, M.K. Mangroves in Indonesia-A case study of Tembilahan, Sumatra. In Restoration of Mangrove Ecosystems; Fields, C., Ed.; International Society for Mangrove Ecosystems: Okinawa, Japan, 1996; pp. 97-110.

80. Rabinowitz, D. Early growth of mangrove seedlings in Panama, and a hypothesis concerning the relationship of dispersal and zonation. J. Biogeogr. 1978, 5, 113. [CrossRef]

81. Kauffman, J.; Donato, D. Protocols for the Measurement, Monitoring and Reporting of Structure, Biomass and Carbon Stocks in Mangrove Forests (Working Paper No. 86); CIFOR: Bogor, Indonesia, 2012.

82. MoE. DRAFT - National Guidelines, Formats and Information for Restoration of Mangrove Ecosystems and Propagation of Mangroves, Sri Lanka; Biodiversity Secretariat, Ministry of Environment: Battaramulla, Sri Lanka, 2021.

83. Worthington, T.A.; Andradi-Brown, D.A.; Bhargava, R.; Buelow, C.; Bunting, P.; Duncan, C. Harnessing big data to support the conservation and rehabilitation of mangrove forests globally. One Earth 2020, 2, 429-443. [CrossRef]

84. Fillyaw, R.M.; Donnelly, M.J.; Litwak, J.W.; Rifenberg, J.L.; Walters, L.J. Strategies for Successful Mangrove Living Shoreline Stabilizations in Shallow Water Subtropical Estuaries. Sustainability 2021, 13, 11704. [CrossRef] 